\title{
Application of extruded broken bean flour for formulation of gluten-free cake blends
}

\author{
Luciana de Oliveira Froes GOMES ${ }^{1}$, Raquel de Andrade Cardoso SANTIAGO², Ana Vania CARVALHO \\ Rosangela Nunes CARVALHO ${ }^{4}$, Iana Gabriela de OLIVEIRA ${ }^{4}$, Priscila Zaczuk BASSINELLO ${ }^{4 *}$
}

\begin{abstract}
Abtract
The aim of this study was to determine the physical and microbiological characteristics of extruded broken beans flour, in addition to developing mixtures for gluten-free cake with these flours, evaluating their technological and sensory quality. Glutenfree formulations were prepared with $45 \%, 60 \%$ and $75 \%$ of extruded broken beans. All analyzes of the flours and mixtures for cakes were performed according to standard techniques found in the literature. Sensory analyzes of cakes applied the 9-point structured hedonic scale. Results were submitted to variance analysis and comparison of means test (Tukey, $\mathrm{p}<0.05)$. The use of extruded broken beans improved the water absorbed and water solubility index of the mixtures for gluten-free cake, and for the lower viscosity and retrogradation when compared to the standard formulation. All cakes were accepted (rate $\geq 7$ ) for all the analyzed attributes. From the technological and sensory standpoints, the development of gluten-free cake mixtures is feasible with up to $75 \%$ of extruded broken beans.
\end{abstract}

Keywords: Phaseolus vulgaris; byproducts; technological characteristics; acceptability.

Practical Application: Nutritive, Healthy, Convenient and Low Cost Gluten-Free Cake Mix of Rice and Beans.

\section{Introduction}

Beans constitute a culture of great economic, social, nutritional and functional importance. Processing is applied in order to adequate these beans for human consumption. Broken beans, fragmented part of grains, are often neglected by the Brazilian industry. Although they cost five times less than whole ones, and present similar nutritional characteristics, the broken grains represent a serious economic problem, but show technological importance (Carvalho et al., 2012a).

Due to inherent physical and chemical characteristics, an alternative to add value to broken beans, and minimize the economic losses, would be the production of extruded broken beans flour (EBF) from this byproduct. The extruded foods market has been increasing rapidly worldwide. Extrusion is a process of industrial cooking that combines moisture, high pressure, heat and mechanic friction for a short period, causing physical and chemical alterations in the foods in order to benefit their technological characteristics (Carreiro et al., 2008).

Recent studies show the viability of EBF as an ingredient in the elaboration of foods for human consumption (Carvalho et al., 2012b; Lopes et al., 2012). An important advantage of the use of this flour has been its capability of replacing wheat flour (WF), mainly in order to meet the needs of a specific group of the population, the celiac individuals. Bakery products for celiac people are of great research interest, since most of them utilize WF as basic ingredient. Among baked products, it is important to underscore the cake, due to the difficulty of achieving acceptability from the complete substitution of WF, especially concerning the texture and the appearance of the product (Kohyama et al., 2007; Moscatto et al., 2004).

Despite cakes being predominantly homemade and crafted in small scale, industrial cakes and ready cake mixes have been conquering the market, mainly the latter, due to their trading benefits conferred by a longer shelf life, facility in transportation and handling, and product diversification (Kohyama et al., 2007). Therefore, the aim of this study was to assess the effect of EBF use regarding the technological and sensory characteristics of gluten-free cake mixes.

\section{Material and methods}

\subsection{Product elaboration}

The broken rice used in the experiment, produced from the processing of commercial varieties of rice, was obtained at Cristal Alimentos Industry, Brazil. The broken kidney beans (Phaseolus vulgaris), generated by the industrial processing of a commercial variety of carioca beans, were provided by Ibiá Alimentos Ltda Industry, Brazil. In order to obtain the flour, the beans were processed with Cyclotec ${ }^{\mathrm{TM}} 1093$ grinding mill (FOSS, Sweden). WF and corn starch (CS) were acquired at the local market. EBF was processed according to the methodology and the parameters established by Carvalho et al. (2012a). 
The cake mixes $(\mathrm{CM})$ were prepared by mixing wheat flour control (100\% WF -control cake - CC) composed by: refined sugar (59.36\%), WF (37.44\%), baking powder (2.97\%) and salt $(0.23 \%)$. Experimental mixes, for gluten-free cakes, were obtained from the total substitution of WF with crude rice flour (CRF), CS and EBF. For the assessment of the EBF technological contribution, it was utilized a complete randomized design, with three treatments of CM containing 45\% (CM45), 60\% (CM60) and 75\% (CM75) of EBF, in addition to $55 \%, 40 \%$ and $25 \%$ of the mixture with $75 \%$ of CRF and $25 \%$ of CS, respectively.

For the assessment of physical, chemical and sensory characteristics of the ready-for-consumption cakes they were prepared on a planetary mixer (Arno Deluxe SX80, Brazil) with the addition of white eggs ( $165 \mathrm{~g})$, margarine $(40 \mathrm{~g})$ and whole milk $(150 \mathrm{~mL})$. The cakes were baked into a pre-heated electric oven (Layr - Luxo $2400 \mathrm{~W} /$ thermocontrol, Brazil) at $180^{\circ} \mathrm{C}$ for 35 minutes.

\subsection{Physical characterization}

Flours and CM were analyzed for moisture, water activity, potential hydrogen, total titratable acidity, water absorption index, water solubility index, paste viscosity and color.Cakes ready-for-consumpiton were analyzed for color, specific volume, density and texture. All analyses, of all samples, were performed in triplicate, except for specific volume and density, which were evaluated in quintuplicate.

Moisture was analyzed by drying at $105^{\circ} \mathrm{C}$ until constant weight. For the determination of water activity $(\mathrm{Aw})$ it was used an Aqualab portable, model-Decagon CX-2 (USA), with onset of digital reading at $25^{\circ} \mathrm{C}$. The values of the hydrogen potential $(\mathrm{pH})$ were measured with direct reading on digital potentiometer (PG 1800 Gehaka, Brazil). Total titratable acidity (TTA) was determined by titration of $0.1 \mathrm{~N} \mathrm{NaOH}$ until the solution reached $\mathrm{pH}$ 8.0. These methods were based on Association of Official Analytical Chemists (2006).

Absorption rates and solubility in water were determined according to the methodology adapted from Okezie \& Bello (1988). A suspension with $25 \mathrm{~mL}$ of distilled water and $0.5 \mathrm{~g}$ of flour (wet basis) was stirred by vortexing for 1 minute and then centrifuged at $3612 \mathrm{~g}$ for 20 minutes. To determine the water solubility index (WSI), an aliquot of $5 \mathrm{~mL}$ of the supernatant was taken and dried to constant weight. To evaluate the water absorbed index (WAI), the rest of the supernatant was carefully drained and the remaining material weighed, being the difference calculated between the sample weight before and after water absorption.

Paste viscosity was determined by Rapid Visco Analyser (RVA, Australia), following the protocol "Rice method" for crude flours (CRF, CBF, WF and CS) and CCM, as well the protocol "Extrusion 1 no-alcohol" to the EBF and cake mixes containing EBF. For the analysis in the RVA, suspensions were used at a concentration of $3.0 \mathrm{~g} / 25 \mathrm{~mL}$ of distilled water, based on the moisture content of $14 \%$. Color was measured with a Hunter Lab colorimeter, Color Quest XE model (USA), being the results expressed by the parameters $L^{*}, a^{*}, b^{*}$ (Hunterlab, 1998).

The ready-for-consumption cakes were evaluated regarding mass and specific volume (SV), according to AACC (American Association of Cereal Chemists, 2000), based on the millet displacement method. Analyses were conducted with five cakes and 17 measurements for specific volume of each formulation, at room temperature. Cake texture was determined in a texture analyzer TA.XTplus (Stable Micro Systems, UK), regularly 16 hours after the baking, using 10 slices $(20 \mathrm{~mm})$ of each sample for section analysis and 10 cylindrical pieces with $35 \mathrm{~mm}$ diameter for compression analysis. For the compression analysis (tension rupture (TR) and energy of rupture), it was used the $50 \mathrm{~mm}$ perspex cylinder probe with a pre-test speed of $1.0 \mathrm{~mm} / \mathrm{s}$, a test speed of $1.0 \mathrm{~mm} / \mathrm{s}$, a post-test speed of $10.0 \mathrm{~mm} / \mathrm{s}$, a tension of $80 \%$, a strength of $3 \mathrm{~g}$, a trigger force of $0.03 \mathrm{~N}$ and a distance of $40 \mathrm{~mm}$. For the analysis of shear (maximal strength for shear and the percentage of stress) the same parameters were used from the cutting probe - BSK.

\subsection{Microbiological analyses}

Every microbiological analysis was performed according to the patterns established by Resolution - $\mathrm{RDC} \mathrm{n}^{\circ} 12$, from the National Sanitation Agency (Brasil, 2001), and followed the procedures described by the American Public Health Association (2001) for each microorganism analyzed. In every sample, it was registered the count of Bacillus cereus and coliforms at $45^{\circ} \mathrm{C}$, and the absence of Salmonella sp. in 25g (Brasil, 2001).

\subsection{Sensory evaluation}

The cakes sensory acceptability analysis was conducted with a 9-point hedonic scale (Stone \& Sidel, 1985). In order to take part in the study, all tasters have signed an informed consent form submitted and approved by the local Ethics Committee (process number 273/2010). On average, 60 potential consumers for each product sample have participated in the sensory analysis, totaling approximately 240 assessors, according to their interest and availability to take part in the analyses. Samples were analyzed in different days and by random tasters, in order to verify the potential acceptability of each formulation, avoiding, thus, the comparison among them, especially pattern interference.

Parameters such as aroma, taste, texture and appearance were sensory evaluated. For the test, samples $(\sim 20 \mathrm{~g})$ were randomly codified with three digits, served in disposable plates, under red light and in individual rooms. Samples appearance was assessed independently, in a well-lit environment during the daytime.

\subsection{Statistical analysis}

Results were expressed as mean and standard deviation of three repetitions and were submitted to variance analysis (ANOVA) and mean comparison test (Tukey, $5 \%$ of probability). Statistical analyses were performed with Statistica software (Statsoft, 2007). 


\section{Results and discussion}

\subsection{Physical characteristics}

The results of the analyzes of physical characteristics of flours and CM are presented in Table 1. All samples presented moisture levels below 15\%, being in accordance to legislation for the studied flours (Brasil, 2005). The moisture values of the cake mixes were lower than individual raw flours probably due to the higher content of sugars in those samples. Regarding Aw, the EBF addition may favor CM stability, since it causes a significant reduction in Aw values (Ferreira et al., 2005).

$\mathrm{pH}$ values of flours suspended in water, are important parameter to be evaluated, once it affect the solubility, so that the higher the $\mathrm{pH}$, the higher the tendency to solubility (Gomes et al., 2006). CM, as well as CBF and EBF, have obtained $\mathrm{pH}$ values close to neutral, which means that the extrusion process has not affected $\mathrm{pH}$, as also verified by Gomes et al. (2006), who described a $\mathrm{pH}$ of 6.37 for $\mathrm{CBF}$ and of 6.28 for $\mathrm{EBF}$ with no significant difference.

Beans have more acidity when compared to other rawmaterial sources utilized, which has reflections on $\mathrm{CM}$, once EBF addition in the formulations has caused a significant TTA increase. Despite presenting statistically significant differences, numerically, the difference among the TTA of CM is low, and will likely not reflect on sensory alterations.

Among all flours utilized in this study, EBF has presented the highest WAI (7.65 g/g gel) with significant difference from the other samples and higher result than that found by Lopes et al. (2012) which was $4.48 \mathrm{~g} / \mathrm{g}$ gel. High water absorption capability is desirable for the preparation of soup, instant porridge and pudding, meat-based products, breads and cakes, for which the high values of WAI are important to help keep the moisture of these products, allowing the addition of more water to the dough, thus improving their handling characteristics (Lopes et al., 2012). Therefore, the use of EBF in gluten-free CM tend to benefit the final product quality, since the higher the EBF percentage in the CM (Table 1), the higher the water absorption $(\mathrm{p}<0.05)$.

The solubility of a product depends on its chemical composition and the interaction between its constitution and water depends greatly on proteins and starch (Lopes et al., 2012). And thus, it may be inferred that the protein-water interaction is much more relevant than the amylose/amylopectin-water relation for WSI, since the flours with higher protein levels have gradually presented higher solubility $(\mathrm{CBF}$ and $\mathrm{EBF}>\mathrm{WF}>\mathrm{CRF}$ and CD) (Universidade Estadual de Campinas, 2011). CM reflects the flours results, once the presence of EBF in the formulations resulted in a significant increase of solubility in water.

Paste properties of the studied flours and the formulated CM are presented in Figures 1A and 1B, respectively. For CBF, the maximum viscosity value $(415.3 \mathrm{cP})$ was higher than that verified by Lopes et al. (2012) (217.0 cP), whereas EBF (140.0 cP) stayed within the range described by the same author ( 85 to $206 \mathrm{cP}$ ). Its lower values when compared to the other flours may be justified both due to the lower carbohydrate content, since starch is the main component in charge of viscosity, and the higher protein amount. Protein content is negatively correlated with maximum viscosity since it functions as a physical barrier for starch swelling, considering that starch granules are enclosed in the protein matrix (Silva et al., 2008).

CM formulations have presented a sudden decrease in viscoamylographic results in relation to the flours. According to Oliveira \& Mancim (2009), the addition of additives and ingredients in pure flours may cause both satisfying and unsatisfying alterations during the cooking stage, interfering, in a very well-defined manner, with the swelling characteristics of the granules.

The significant reduction in the final viscosity of EBF $(338.7 \mathrm{cP})$ in relation to $\mathrm{CBF}(885.7 \mathrm{cP})$ may have occurred due to the starch granules degradation and possible molecular structures rupture during the extrusion process. Moreover, during the cooling process, in natura starch pastes normally tend to retrogradation, and consequently, to an increase in final viscosity, which also justifies the higher values for CRF, WF and CS (Silva et al., 2008).

The substitution of WF with CRF, EBF and CS has caused significant and gradual reduction $(\mathrm{p}<0.05)$ of final viscosity and retrogradation for the $\mathrm{CM}$, in accordance with the rawmaterials' results, that is, the higher the quantity of EBF, the

Table 1. Values of moisture, water activity (Aw), pH, total titratable acidity (TTA), water absorption index (WAI), water solubility index (WSI) and color parameters of flours and gluten-free cake mixesa.

\begin{tabular}{|c|c|c|c|c|c|c|c|c|c|}
\hline \multirow{2}{*}{ Samples ${ }^{\mathrm{b}}$} & \multirow[b]{2}{*}{ Moisture } & \multicolumn{5}{|c|}{ Physical propertiesc } & \multicolumn{3}{|c|}{ Colorc } \\
\hline & & Aw & $\mathrm{pH}$ & TTA (\%) & WAI (g/g gel) & WSI (\%) & $\mathrm{L}^{*}$ & $a^{*}$ & $\mathrm{~b}^{*}$ \\
\hline CRF & $8.77 \pm 0.05^{3}$ & $0.47 \pm 0.00^{4}$ & $6.19 \pm 0.01^{2}$ & $0.15 \pm 0.01^{3}$ & $2.94 \pm 0.12^{3}$ & $2.18 \pm 0.14^{3}$ & $91.05 \pm 0.13^{2}$ & $-0.13 \pm 0.00^{4}$ & $5.88 \pm 0.05^{3}$ \\
\hline $\mathrm{CBF}$ & $8.46 \pm 0.04^{4}$ & $0.52 \pm 0.00^{3}$ & $6.46 \pm 0.11^{1}$ & $1.05 \pm 0.01^{1}$ & $5.23 \pm 0.08^{2}$ & $37.46 \pm 0.72^{1}$ & $84.61 \pm 0.01^{4}$ & $1.27 \pm 0.02^{2}$ & $8.09 \pm 0.05^{2}$ \\
\hline WF & $11.06 \pm 0.03^{1}$ & $0.65 \pm 0.00^{1}$ & $5.95 \pm 0.03^{3}$ & $0.15 \pm 0.00^{3}$ & $2.49 \pm 0.05^{3,4}$ & $8.43 \pm 0.21^{2}$ & $88.73 \pm 0.05^{3}$ & $0.71 \pm 0.01^{3}$ & $10.49 \pm 0.03^{1}$ \\
\hline CS & $10.43 \pm 0.11^{2}$ & $0.60 \pm 0.00^{2}$ & $5.01 \pm 0.06^{4}$ & $0.16 \pm 0.01^{3}$ & $2.15 \pm 0.14^{4}$ & $2.27 \pm 0.26^{3}$ & $93.57 \pm 0.33^{1}$ & $-0.59 \pm 0.00^{5}$ & $5.57 \pm 0.02^{3}$ \\
\hline CM60 & $2.45 \pm 0.03^{c}$ & $0.45 \pm 0.00^{\mathrm{b}}$ & $6.90 \pm 0.10^{\mathrm{a}}$ & $0.38 \pm 0.02^{\mathrm{b}, \mathrm{c}}$ & $9.27 \pm 0.25^{\mathrm{b}}$ & $82.34 \pm 0.71^{\mathrm{b}}$ & $83.96 \pm 0.05^{c}$ & $1.64 \pm 0.02^{\mathrm{b}}$ & $9.21 \pm 0.08^{c}$ \\
\hline CM75 & $2.49 \pm 0.04^{c}$ & $0.43 \pm 0.00^{c}$ & $6.74 \pm 0.06^{\mathrm{a}}$ & $0.68 \pm 0.05^{\mathrm{a}}$ & $13.01 \pm 0.71^{\mathrm{a}}$ & $86.03 \pm 1.11^{\mathrm{a}}$ & $82.90 \pm 0.14^{\mathrm{d}}$ & $1.80 \pm 0.01^{\mathrm{a}}$ & $9.57 \pm 0.15^{\mathrm{b}}$ \\
\hline
\end{tabular}

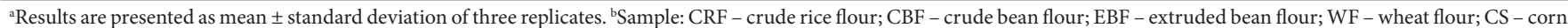
starch; CC - control cake; CM45 - cake mix with $45 \%$ of EBF; CM60 - cake mix with $60 \%$ of EBF; CM75 - cake mix with $75 \%$ of EBF. ${ }^{\mathrm{C}}$ Means with numbers among flours and with letters among cake mixes, when equal and in the same column, do not differ significantly (Tukey test, $\mathrm{p}<0.05$ ). 

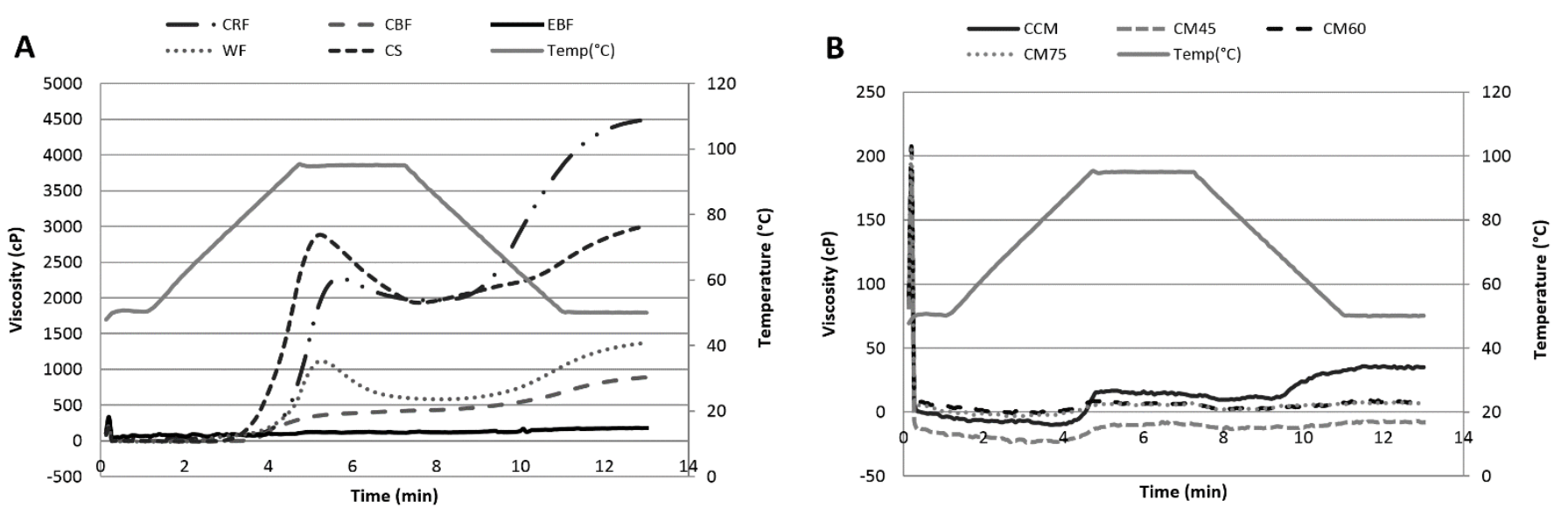

Figure 1. A: Viscoamilogram of flours: CRF (crude rice flour), CBF (crude bean flour), EBF (extruded bean flour), WF (wheat flour) and CS (corn starch). B: Viscoamilogram of cake mixes: CC (control cake ), CM45 (cake mix with 45\% of EBF), CM60 (cake mix with 60\% of EBF), CM75 (cake mix with $75 \%$ of EBF).

lower the retrogradation. Therefore, ready-for-consumption cakes with higher EBF substitution tend to better conserve the bonds with water molecules, resulting in moister samples and possibly higher acceptability, since retrogradation is an undesirable characteristic in cakes.

Color instrumental parameters of flours and $\mathrm{CM}$ are presented in Table $1 . \mathrm{L}^{*}$ component value of $\mathrm{CBF}$ was $4.8 \%$ higher than that of EBF, indicating luminosity reduction from the extrusion process. This process, however, has caused chromaticity coordinates $\mathrm{a}^{*}$ and $b^{\star}$ to increase, confirming the darkening of the flour. The color acquired by EBF may be the result of sugar caramelization or the occurrence of Maillard reaction, since beans flour presents a large quantity of carbohydrates and proteins (Pelembe et al., 2002; Carreiro et al., 2008).

As expected, CM and ready-for-consumption cake had gradual and significant decrease in $\mathrm{L}^{*}$ values according to the raise in EBF percentage. Canella-Rawls (2006) stated that food appearance is markedly relevant for its acceptability, and explains why color is one of the most important sensory properties for foods, both natural and processed. A darker color is normally perceived as the presence of whole flours, or due to the cake flavor, as in the case of chocolate and nut cakes (Canella-Rawls, 2006), which may benefit the use of EBF in gluten-free CM with no acceptability loss.

The experimental cakes' SV are presented in Table 2. It is noted that significant differences $(\mathrm{p}<0.05)$ among all samples, with CC $\left(4.64 \mathrm{~mL} / \mathrm{g}^{-1}\right)$ shown the highest SV, that is, with higher expansion during baking. The main reason why CC stands out in regard to the other cakes is that it is the only with WF, being $100 \%$ of the flour amount in the dough. Among all applied flours as ingredient for the cakes elaboration, WF is the only one that has gluten-forming proteins (gliadin and glutenin). These proteins have the function of forming an elastic chain for the capture of expanding gases produced by chemical reaction of baking powder enzymes in the dough, providing the cake with its structure. Gluten absence impairs the retention of these gases, and, thus, dough development (Canella-Rawls, 2006).
Even with lower SV than CC, the other cakes presented better development when compared to other studies, for instance, gluten-free cakes with rice flours and cassava peel and pulp flours which demonstrated growth between 1.2 and $1.9 \mathrm{~mL} / \mathrm{g}^{-1}$ (Souza et al., 2013). Gularte et al. (2011) have also developed gluten-free cakes when rice flour was substituted with the flour of several legumes, obtaining a SV of $2.9 \mathrm{~mL} / \mathrm{g}^{-1}$ for the cake with $50 \%$ of beans flour, being this value close to that of CM60 in the present study.

The differences $(\mathrm{p}<0.05)$ of SV and density among CM45, CM60 and CM75 may be explained by the gradual and respective increase of EBF in the formulations. Beans presented the higher content of total dietary fiber compared to other raw materials used (Bassinello et al., 2011; Carvalho et al., 2012a; Universidade Estadual de Campinas, 2011; Silva et al., 2009), and according to Souza et al. (2013), the fibers are long chain polymers that impair the aeration process of the mass, since they are able to disrupt the structure of the dough and release the trapped air, responsible for aeration in bakery products such as breads and cakes. Increasing EBF also promotes lower starch retrogradation in the cake, which leads to greater moisture retention. SV and density clearly show the relationship between the solids content and the fraction of air in the baked dough. Dough with high density or low SV (compacted) present unappealing to consumers, associated with high moisture content, flawed beating and cooking, poor aeration, hard to chew, improper taste and low maintenance (Esteller \& Lannes, 2005).

The effect of CRF and EBF on texture properties of the cakes is presented in Table 2 . The data indicate that the gradual addition of EBF induced a significant increase $(\mathrm{p}<0.05)$ in the cakes' TR and the energy of rupture, indicating that the presence of beans in the formulation tends to increase the product firmness. These data represent the analysis of compression, where the TR is the strength applied in a fixed area of the cake needed to cause disruption of its structure up to $80 \%$ of deformation in relation to its initial height. The energy in the rupture reflects the amount of energy required to cause cake rupture, being a physical parameter that depends on the strength and respective deformation. The 
Table 2. Physical and sensory analyses of ready-for-consumption cakesa.

\begin{tabular}{|c|c|c|c|c|c|c|c|c|}
\hline \multirow[b]{2}{*}{$\begin{array}{l}\text { Analysis / } \\
\text { Samplesb }\end{array}$} & \multirow[b]{2}{*}{$\mathrm{SV}\left(\mathrm{mL} / \mathrm{g}^{-1}\right)$} & \multirow[b]{2}{*}{ Density } & \multicolumn{4}{|c|}{ Compression } & \multicolumn{2}{|c|}{ Shearing } \\
\hline & & & \multicolumn{2}{|c|}{$\mathrm{TR}^{\mathrm{c}}(\mathrm{kPa})$} & \multicolumn{2}{|c|}{ Energy $(\mathrm{kJ})$} & $\begin{array}{l}\text { Maximal strength } \\
(\mathrm{N})\end{array}$ & $\begin{array}{l}\text { Deformation } \\
(\%)\end{array}$ \\
\hline $\mathrm{CC}$ & $4.64 \pm 0.22^{1}$ & $0.27 \pm 0.02^{4}$ & \multicolumn{2}{|c|}{$20027.02 \pm 3053^{3}$} & \multicolumn{2}{|c|}{$0.08 \pm 0.01^{3}$} & $2.60 \pm 0.15^{3}$ & $97.07 \pm 2.08^{1}$ \\
\hline CM60 & $2.96 \pm 0.09^{3}$ & $0.42 \pm 0.02^{2}$ & \multicolumn{2}{|c|}{$53128.28 \pm 7759^{1}$} & \multicolumn{2}{|c|}{$0.22 \pm 0.02^{2}$} & $3.84 \pm 0.39^{2}$ & $88.83 \pm 2.87^{2}$ \\
\hline CM75 & $2.61 \pm 0.09^{4}$ & $0.50 \pm 0.02^{1}$ & \multicolumn{2}{|c|}{$56992.89 \pm 8375^{1}$} & \multicolumn{2}{|c|}{$0.26 \pm 0.03^{1}$} & $4.45 \pm 0.28^{1}$ & $90.20 \pm 2.33^{2}$ \\
\hline $\mathrm{CC}$ & $65.43 \pm 0.78^{1}$ & $2.7 \pm 0.19^{3}$ & $28.81 \pm 0.80^{1}$ & \multicolumn{2}{|c|}{$8.16 \pm 0.95^{1}$} & $7.63 \pm 1.60^{1}$ & $7.44 \pm 1.48^{1}$ & $7.73 \pm 1.53^{1}$ \\
\hline CM45 & $53.74 \pm 0.99^{2}$ & $6.89 \pm 0.25^{2}$ & $19.02 \pm 0.58^{2}$ & \multicolumn{2}{|c|}{$7.34 \pm 1.21^{2,3}$} & $7.65 \pm 1.42^{1}$ & $7.70 \pm 1.29^{1}$ & $7.15 \pm 1.81^{1,2}$ \\
\hline CM60 & $47.47 \pm 0.83^{3}$ & $8.26 \pm 0.34^{1}$ & $20.80 \pm 0.93^{2}$ & \multicolumn{2}{|c|}{$7.71 \pm 1.25^{1,2}$} & $7.79 \pm 1.46^{1}$ & $7.56 \pm 1.47^{1}$ & $6.66 \pm 1.98^{2}$ \\
\hline CM75 & $48.40 \pm 1.50^{3}$ & $7.79 \pm 0.51^{1}$ & $19.24 \pm 0.74^{2}$ & \multicolumn{2}{|c|}{$7.11 \pm 1.51^{3}$} & $7.96 \pm 1.26^{1}$ & $7.60 \pm 1.40^{1}$ & $7.44 \pm 1.52^{1}$ \\
\hline
\end{tabular}

higher the voltage or energy, the more resistant to deformation by the application of a force in compression the cake is, and therefore firmer and more intact the structure of the dough is (Cechi, 2007). The property of legumes to promote greater hardness of cakes was also reported by Gularte et al. (2011) who found a significant increase in hardness and chewiness of cakes prepared with beans, chickpeas and peas. These authors reported a negative relationship between cakes' hardness and SV, which numerically could also be observed in this study (Table 2 ). The reason for this relationship is the presence of gluten (in WF) which favors the SV and reduces the hardness of the cake due to the formation of a proteic network that expands more, with more air retention, and presents improved stability after withdrawal from the oven when compared to the network formed by the proteins in the other flours, such as EBF and CRF.

In the shearing analyses, the maximum force indicates the energy required to cause the first rupture of the sample (Cechi, 2007). Therefore, in this study it was verified that the higher the amount of EBF, the more energy was expended to promote the rupture of the cakes (Table 2). An explanation for that relies on the fact that gluten-free cakes prepared with CRF and EBF show a lower expansion during baking, and for that reason, also present their components more condensed, making them physically more difficult to break (Canella-Rawls, 2006). Besides the physical issue, it is possible that the molecular bonds between $\mathrm{EBF}$ and the other cake compounds are stronger than those formed by the WF, requiring more energy to break them (Gularte et al., 2011).

Regarding the deformation percentage during the shearing of the cakes, the results showed that the total replacement of WF with CRF and EBF may not cause a significant difference (CM45), however data also showed that increasing the amount of EBF in the cake formulation causes a significant decrease in its values (CM60 and CM75). The highest percentage of deformation may indicate the cake took longer to undergo the cut, and thus, there is a chance that the cakes with greater deformation also show greater elasticity (Baixauli et al., 2008). Thus, it is noteworthy that Gularte et al. (2011), when using some legumes (chickpeas, lentils and beans) have obtained an increased elasticity of the cakes.

\subsection{Microbiological quality}

The microbiological studies for flours, CM and ready cakes showed that all samples were in accordance with the patterns established by RDC n 12 from the National Sanitation Agency. All analyzed microorganisms were below the threshold, thus demonstrating that the raw-material (flours) present microbiological safety for human consumption and that the handling process of CM and ready-for-consumption cakes was adequate for microorganism control (Brasil, 2001).

\subsection{Sensory acceptability}

Acceptability results (Table 2) demonstrated that all formulations were accepted (scores $>6$ ) regarding taste, aroma, texture and appearance. Cakes presented scores between 7 (liked moderately) and 8 (liked a lot) for all attributes, except CM60, which received the mean score between 6 (liked slightly) and 7 for texture, and CC that attained the appearance mean between scores 8 and 9 (liked greatly).

The lower gluten-free cakes' appearance scores, when compared to CC $(\mathrm{p}<0.05)$, may be partially explained by the more compact structure and low volume, in addition to a darker color, diverging from the patterns expected by average consumers of simple cakes (Canella-Rawls, 2006). Despite CC's higher score $(\mathrm{p}<0.05)$, all other formulations (CM45, CM60 and CM75) had higher scores than other cakes tested with partial substitution of WF, ranging from 6.4 to 6.6 (Moscatto et al., 2004; Silva et al., 2009), in addition to having similar scores as found by Souza et al. (2013) (7.0) and Wang et al. (2005) (7.73), for cakes tested with mixed rice, cassava peel or pulp flours, and wheat and extruded soy flours, respectively.

For taste and aroma analyses there were no significant differences $(\mathrm{p}>0.05)$ between samples, with relative increase of scores according to the increase of EBF percentage in the 
formulation. Bassinello et al. (2011) and Carvalho et al. (2012b) have also reported good acceptability of cookies and snack. Moreover, the score means of rice and EBF cakes were higher than the score means reported for cakes elaborated with other flours, ranging from 6.3 to 7.3 for taste, and from 6.4 to 7.1 for aroma (Moscatto et al., 2004; Silva et al., 2009; Souza et al., 2013).

The mean values of texture sensory test obtained from CC, CM45 and CM75 have not presented significant difference ( $>0.05)$, indicating that there is good acceptability for this attribute from the most tender to the most compact and resistant product. These results are in accordance with those found in literature (Wang et al., 2005, Moscatto et al., 2004). Moreover, these results show that the significant difference found in the texture instrumental analysis among CC, CM45 and CM75 has not affected $(p>0.05)$ sensory analysis. The sum of all data presented suggests good acceptability by consumers, for EBF addition as a potential ingredient for the elaboration of diversified food products.

\section{Conclusion}

Gluten-free cake mix is noteworthy for the lower values of Aw, better WAI and WSI, and for the lower viscosity and retrogradation when compared to the standard formulation. The darker color of cakes with EBF, as well as lower SV and tenderness, has not impaired the product's good sensory acceptability. From the technological, nutritional and sensory perspectives, the utilization of EBF is viable and recommended in the food industry to partially substitute WF, or the flour of other gluten-free cereals, with the objective of adding economic value to the beans byproducts and diversifying the bakery market.

\section{Acknowledgements}

The authors are grateful to Ibiá Alimentos Ltda (Goiânia-GO), for the donation of broken beans samples; to Coordenação de Aperfeiçoamento de Pessoal de Nível superior (CAPES) for the fellowship granted to Luciana de Oliveira Froes Gomes and to Gilsimeire Bastos Morais, for the support with data collection.

\section{References}

American Association of Cereal Chemists - AACC. (2000). Approved Methods of Analysis: guidelines for measurement of volume by rapeseed displacement (11th ed.). St. Paul, MN: AACC International.

American Public Health Association - APHA. (2001). Compendium of methods for the microbiological examination of foods (4th ed). Washington: APHA.

Association of Official Analytical Chemists - AOAC. (2006). Official methods of analysis of AOAC International (18th ed.). Gaithersburg: AOAC International.

Baixauli, R., Salvador, A., \& Fiszman, S. M. (2008). Textural and colour changes during storage and sensory shelf life of muffins containing resistant starch. European Food Research and Technology, 226(3), 523-530. http://dx.doi.org/10.1007/s00217-007-0565-4.

Bassinello, P. Z., Freitas, D. G. C., Ascheri, J. L. R., Takeiti, C. Y., Carvalho, R. N., Koakuzu, S. N., \& Carvalho, A. V. (2011). Characterization of cookies formulated with rice and black bean extruded flours.
Procedia Food Science, 1(1), 1645-1652. http://dx.doi.org/10.1016/j. profoo.2011.09.243.

Brasil. Agência Nacional de Vigilância Sanitária - ANVISA. (2001). Aprova o regulamento técnico sobre os padróes microbiológicos para alimentos (Resolução RDC nº 12, de 02 de janeiro de 2001). Diário Oficial [da] República Federativa do Brasil. Retrieved from http:// portal.anvisa.gov.br/wps/wcm/connect/a47bab8047458b909541d 53fbc4c6735/RDC_12_2001.pdf?MOD=AJPERES

Brasil. Agência Nacional de Vigilância Sanitária - ANVISA. (2005). Aprova o regulamento técnico para produtos de cereais, amidos, farinhas e farelos (Resolução RDC $n^{\circ} 263$, de 22 de setembro de 2005). Diário Oficial [da] República Federativa do Brasil. http:// portal.anvisa.gov.br/wps/wcm/connect/1ae52c0047457a718702d 73fbc4c6735/RDC_263_2005.pdf?MOD=AJPERES

Canella-Rawls, S. (2006). Pão: arte e ciência (2nd ed.). São Paulo: Senac São Paulo. 320 p.

Carreiro, A., Godoy, A., Lima, A. C., Tavares, C., Lopes, D., \& Magalhães, V. A. (2008). Alimentos extrusados. São Paulo: Faculdade de Ciências Farmacêuticas, Universidade de São Paulo.

Carvalho, A. V., Rios, A. O., Bassinello, P. Z., \& Ferreira, T. F. (2012a). Efeito dos parâmetros de extrusão termoplástica sobre as propriedades tecnológicas de farinhas pré-cozidas elaboradas com arroz e feijão. Brazilian Journal of Food Technology, 15(4), 343-342. http://dx.doi. org/10.1590/S1981-67232012005000029.

Carvalho, A. V., Bassinello, P. Z., Mattietto, R. A., Carvalho, R. N., Rios, A. O., \& Seccadio, L. L. (2012b). Processamento e caracterização de snack extrudado a partir de farinhas de quirera de arroz e de bandinha de feijão. Brazilian Journal of Food Technology, 15(1), 7283. http://dx.doi.org/10.1590/S1981-67232012000100008.

Cechi, H. M. (2007). Fundamentos teóricos e práticos em análise de alimentos (2nd ed.). Campinas: UNICAMP. 207 p.

Esteller, M. S., \& Lannes, S. C. S. (2005). Parâmetros complementares para fixação de identidade e qualidade de produtos panificados. Ciência e Tecnologia de Alimentos, 25(4), 802-806. http://dx.doi. org/10.1590/S0101-20612005000400028.

Ferreira, C. J., No., Figueirêdo, R. M. F., \& Queiroz, A. J. M. (2005). Avaliação sensorial e da atividade de água em farinhas de mandioca temperadas. Ciência e Agrotecnologia, 29(4), 795-802. http://dx.doi. org/10.1590/S1413-70542005000400011.

Gomes, J. C., Silva, C. O., Costa, N. M. B., \& Pirozi, M. R. (2006). Desenvolvimento e caracterização de farinhas de feijão. Revista Ceres, 53(309), 548-558.

Gularte, M. A., Gómez, M., \& Rosell, C. M. (2011). Impact of legume flours on quality and in vitro digestibility of starch and protein from gluten-free cakes. Food Bioprocess Technology, 31, 195-202. http:// dx.doi.org/10.1007/s11947-011-0642-3.

Hunterlab. (1998). User's manual with universal software versions 3.5. Reston: Hunterlab.

Kohyama, K., Sawada, H., Nonaka, M., Kobori, C., Hayakawa, F., \& Sasaki, T. (2007). Textural Evalution of rice cake by chewing and swallowing measurements on human subjects. National Food Research Institute, 71(2), 358-365. http://dx.doi.org/10.1271/bbb.60276.

Lopes, L. C. M., Batista, K. A., Fernandes, K. F., \& Santiago, R. A. C. (2012). Functional, biochemical and pasting properties of extruded bean (Phaseolus vulgaris) cotyledons. International Journal of Food Science \& Technology, 47(9), 1859-1865. http://dx.doi.org/10.1111/ j.1365-2621.2012.03042.x.

Moscatto, J. A., Prudêncio-Ferreira, S. H., \& Hauly, C. O. M. (2004). Farinha de yacon e inulina como ingredientes na formulação de 
bolo de chocolate. Ciência e Tecnologia de Alimentos, 24(4), 634-640. http://dx.doi.org/10.1590/S0101-20612004000400026.

Okezie, B. O., \& Bello, A. B. (1988). Physico chemical and functional properties of winged bean flour and isolate compared with soy isolate. Journal of Food Science, 53(2), 450-454. http://dx.doi. org/10.1111/j.1365-2621.1988.tb07728.x.

Oliveira, J. H., Fo., \& Mancim, A. C. (2009). Aditivos e ingredientes e seus reflexos sobre as propriedades viscoamilográficas de amido de milho. Brazilian Journal of Food Technology, 11, 78-84.

Pelembe, L. A. M., Erasmus, C., \& Taylor, J. R. N. (2002). Development of a protein-rich composite sorghum-cowpea instant porridge by extrusion cooking process. LWT - Food Science and Technology, 35(2), 120-127. http://dx.doi.org/10.1006/fstl.2001.0812.

Silva, E. M. M., Ascheri, J. L. R., Ascheri, D. P. R., \& Carvalho, L. J. (2008). Efeito dos parâmetros de extrusão nas características de viscosidade de pasta e índice de absorção de água de macarrões pré-cozidos elaborados a partir de farinha mista de arroz integral e milho obtidos por extrusão. Boletim do Centro de Pesquisa e Processamento de Alimentos, 26(2), 239-254.
Silva, R. F., Ascheri, J. L. R., Pereira, R. G. F. A., \& Modesta, R. D. C. (2009). Aceitabilidade de biscoitos e bolos à base de arroz com café extrusados. Ciência e Tecnologia de Alimentos, 29(4), 815-819. http:// dx.doi.org/10.1590/S0101-20612009000400018.

Souza, T. A. C., Soares, M. S., Jr., Campos, M. R. H., Souza, T. S. C., Dias, T., \& Fiorda, F. A. (2013). Bolos sem glúten a base de arroz quebrado e casca de mandioca. Semina, 34, 717-728. http://dx.doi. org/10.5433/1679-0359.2013v34n2p717

Statsoft (2007). STATISTICA for Windows - Computer program manual. Tulsa: Statsoft Inc. Retrieved from www.statsoft.com

Stone, H., Sidel, J. L. (1985). Affective testing. In H. Stone \& J. L. Sidel (Eds.), Sensory evaluation pratices (pp. 227-252). Boca Raton: Academic Press. http://dx.doi.org/10.1016/B978-0-12-672480-6.50011-1.

Universidade Estadual de Campinas - UNICAMP. (2011). Tabela brasileira de composição de alimentos - TACO (4th Rev. ampl. ed.). Campinas: UNICAMP/NEPA.

Wang, S. H., Rocha, G. O., Nascimento, T. P., Ascheri, J. L. R., \& Oliveira, A. (2005). Características sensoriais de bolos esponja preparados com farinhas de trigo e soja extrusadas em diferentes parâmetros de extrusão. Alimentos e Nutrição, 16(4), 369-376. 